\title{
Adaption of Marketing Mix for Selected Country
}

\author{
Barbora Szolgayová ${ }^{1, *}$ \\ ${ }^{1}$ Institute of Technology and Business, Faculty of Corporate Strategy, Okružní 517/10, České Budějovice, Czech Republic
}

\begin{abstract}
Using the SWOT analysis, it was found that Kofola Plc. is in a sufficiently strong position to enter the foreign market, specifically the Austrian market, and the competition in the Austrian market was further analysed. It showed that there are three major competitors in the market. Using the PEST analysis, information concerning the exchange of goods and exports, or the financial situation of Austrian citizens was found. The company's marketing mix on the Czech market and its subsequent adaptation to the Austrian market were described. The greatest need for adaptation was identified in the marketing communication and also in the product itself, specifically packaging, which will require a language mutation in the composition. Also, some change in appearance to match the marketing communication will be needed. The marketing communication will focus mainly on the unique taste of Kofola, which could be an attraction for potential customers, mainly because Austrians already like the herbal drink made by Almdudler, which is also one of the company's competitors, together with Coca - Cola Austria and PepciCo.
\end{abstract}

Keywords: adaption of marketing mix; marketing mix; international marketing; marketing strategy; analysis; marketing

\section{Introduction}

This article on the topic of adaptation of the marketing mix for a selected country deals with the issue of the marketing mix of the traditional Czech company Kofola Česko Slovensko Plc., given that the portfolio of this brand is very extensive, this article will focus on one of the subsidiaries, Kofola Plc. (hereinafter referred to as Kofola). The marketing mix will be adapted to one of the neighbouring countries to the Czech Republic, namely the Republic of Austria. This company already operates in several foreign markets. Austria was chosen for several reasons. The first is a certain similarity between the two countries - the adaptation of the marketing mix will not be as difficult as, for example, in third world countries. Furthermore, due to the considered distribution routes, neighbouring countries are considered the most suitable. Kofola has already been operating on the Czech, Slovak and Polish markets for many years, so the German and Austrian markets are possible. After considering both options, the Austrian market was evaluated as a more suitable option.

\section{Literary research}

The selected topic of this article is extensive and contains many definitions and concepts. A large amount of quality literature is written on the topic of the marketing mix, and overall, a wide range of information is available from different sources.

From foreign sources, the author Philip Kotler and his book Principles of Marketing [1] definitely should be mentioned. The basics of marketing or marketing mix are clearly explained in this book. Another very interesting author is Seth Godin [2]. In 2018, he published the book This is Marketing, where the main idea of his approach is that big marketers do not use consumers to solve society's problems but use marketing to solve other people's problems.

A group of authors calling themselves 50 Minutes has published The Marketing Mix [3], which will provide the reader with a practical introduction to each component of the so-called $4 \mathrm{P}$ (product, price, promotion and distribution). The main attraction is the guarantee of understanding the basics of the marketing mix in just 50 minutes. The work Marketing obchodní firmy [4] by M. Zamazalová is one of the few books that is directly intended for Czech readers and describes the conditions on the Czech market and contains many practical examples from Czech companies. In the article The 4P Classification of Making Mixing Revisited from 2015, the authors W. van Waterschoot and CH. van den Bulte [5] deal with the basic concept of the so-called $4 \mathrm{P}$ and its revision. The author Roxana Codita [6] in the book Contingency factors of marketing-mix standardization focuses on the issue of standardization of the marketing mix in connection with Central and Eastern Europe. The Concept of 'Marketing Mix' and its Element is an article describing the mix in its extended concept of "8P" (4P + people, processes, physical records, productivity and quality) by M. T. Khan [7]. The second edition of Marketing in Tourism [8], written by the author Dagmar Jakubíková, deals with marketing tools and the customer's

\footnotetext{
* Corresponding author: $16477 @$ mail.vstecb.cz
} 
view is underlined here. In the article by Efthymios Constantinides [9], titled The Marketing Mix Revisited, it is possible to find a summary of literature reviews dealing with marketing, mix or relationship marketing.

The work Strategic Marketing [10] also by Dagmar Jakubíková, in which she generally deals with the issue of strategic marketing, from the management process to situation analyses. Already the fifth edition of the publication Marketing Strategy and Management [11] by Michael Baker includes the classic concept of the so-called "4P", but also new research, current examples or case studies, and also offers several perspectives on the creation and implementation of marketing strategy.

A number of authors also deal with international marketing, such as Tobias Richter [12], who wrote Management International Marketing Mix. It focuses on international marketing strategy and the related marketing mix of world markets. Other authors dealing with the same issues are, for example, Bohumír Štědroň, who, together with other authors, wrote the book International Marketing [13], in which he deals mainly with simple models, concepts and deciding how and which foreign market to enter. Prrikrylová and Machková also deal with modern marketing communication $[14,15]$.

\subsection{Research questions}

The above-mentioned Machková [16] is also the author of the publication International Marketing, in which she deals with strategic trends. The publication Basics of Marketing by the author Miroslav Karlíček [17] describes the basic issues of marketing, what strategy to choose, what price to set, how to create the right product or how to adapt the marketing mix. Destination Marketing Management is a publication by Monika Palatková [18], who focuses on marketing strategy, especially the marketing mix and its adaptation, and the organization of marketing management, and last but not least, Gerald A. [19], who wrote the book International Marketing and Export Management in 2005, focused on international marketing and export-related management processes.

This article will focus on the basic concept of the marketing mix and its adaptation to the selected country, Austria.

1. How many competing companies operating in Austria provide a similar product?

2. Which area of the $4 P$ marketing mix will be needed to be most adapted for the selected market?

\section{Methodology}

For the adaptation of the marketing mix, as already mentioned in the introduction, the author chose one of the neighbouring countries of the Czech Republic, namely the Republic of Austria. Austria has been a very important trading partner of the Czech Republic for a long time and vice versa. Austria is ranked among the ten richest countries in the world due to its high GDP per capita. Despite its relatively small area and population, this is a very interesting market with strong domestic purchasing power. The Austrian market is very advanced in terms of marketing and global companies are there. It can be really challenging to enter the Austrian market. Companies offering products with high added value, but only while maintaining a price advantage over the competition, can succeed.

For a successful marketing campaign, it will be very important to choose the right promotion and also the marketing preparation, which is a key point for success in this market, as well as in similarly developed markets. The mentality of Austrian citizens is similar to the Czech mentality, so it should not be difficult to empathize with the needs and wishes of these customers, as for example with the German neighbours.

As for the costs of promotion, they are of course higher than in the Czech Republic, especially in terms of the media. This is also the main reason why they have heard so little about Czech products in this country so far and also because some companies may underestimate the importance of advertising and promotion on the Austrian market.

\subsection{Methodology of the research}

The topic of this paper is the adaptation of the marketing mix to the selected country. The marketing mix of Kofola Plc. will be adapted. This company is already very well known to me, thanks to the author's bachelor's thesis, which was focused on the marketing communication of this company.

The author determined the main goal of this work, namely, to answer two research questions (see the research questions chapter). First of all, she would like to create a SWOT analysis and find out what situation the company is in, whether it will be in a strong enough position to enter a new market. She also evaluated the company's current marketing mix in the Czech Republic. The author would also like to create a competition research survey and PEST analysis. It predicts and analyses the future influences that will affect the company in the Austrian market, so that she has an idea of what the company will face in the market. Subsequently, an adapted marketing mix for the Austrian market will be created. After addressing this whole issue, clear answers to the research questions asked should emerge. 


\subsection{Introduction of Kofola PIc.}

Kofola Plc., (hereinafter referred to as Kofola), as already mentioned, falls under the parent company Kofola ČeskoSlovensko Plc, which is one of the largest producers of soft drinks in several European markets. This company was founded in the 1950s. In 1957, a pharmaceutical company was given the task of developing and subsequently producing a soft drink that can replace foreign cola drinks. Two years later, KOFO syrup was developed from which Kofola is still made.

\subsection{Research methods}

\section{SWOT analysis}

This chapter will identify the strengths and weaknesses of the company, as well as its opportunities and threats, which will provide an overview of the current situation of the company. The SWOT analysis will point out those areas on which the company will be able to rely in the future, and vice versa, areas that need to be improved or eliminated.

Strengths and weaknesses show the internal situation of the company and show factors that can affect the company positively or negatively and affect the future prosperity of the company at the same time.

\section{Strengths}

- strong position on the Czech and Slovak market

- financial stability

- traditional Czech brand

- brand knowledge

- marketing activities

- Kofola drink composition

- favourable price compared to the competition

- strong customer support

- Kofola on tap

- strong local brand

- wide portfolio

Kofola has a very strong position on the Czech and Slovak markets (see Fig. 1). According to internal materials, the company has been developing in a positive direction in recent years, 2018 was a growth year for the company. It is a traditional Czech brand that has strong ties with customers. The drink became known also thanks to sophisticated marketing activities, especially in terms of advertising. The composition of this beverage has certain advantages over competing cola drinks, it does not contain phosphoric acid and contains less sugar and caffeine. The price is also a bit more favourable than the competition's, and it is also a certain plus that it is possible to buy Kofola on tap.

\section{Weaknesses}

- long-term number two on the Czech market in the area of cola drinks (see Fig. 1)

- the association of kofola and communism

- brand knowledge only in the Czech Republic and Slovakia

- pressure from retail chains on margins

- very little chance that Kofola will get to restaurants where its competitor already operates

- climate dependence

- taste

Kofola has long been the second largest player on the Czech market in the field of cola drinks, and its strongest competitor is Coca-Cola (see Figure 1). Another disadvantage is the association of the Kofola brand with communism, which may discourage some customers although the company is wholly owned by different owners than before. As far as foreign countries are concerned, the Kofola brand is known only in the Czech Republic and Slovakia, in other countries where the company operates under the name Hoop. Unification under the same name could strengthen the company's position in other markets. 


\section{ČR: HoReCa segment}

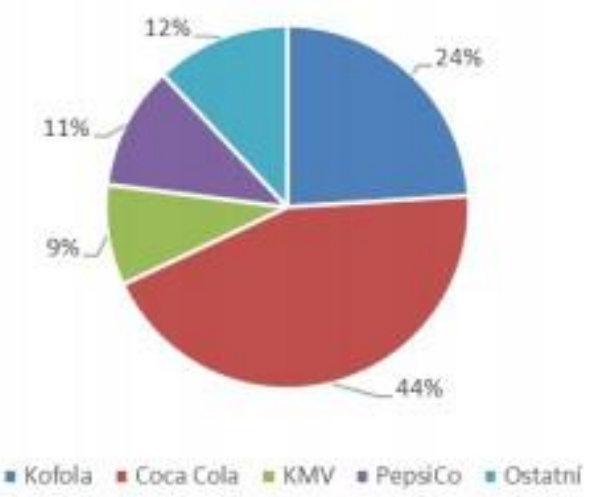

\section{Slovensko: HoReCa segment}

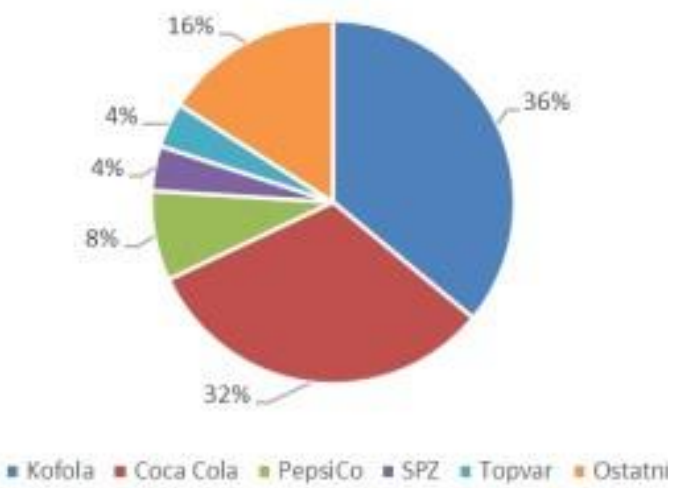

Figure 1. Kofola market shares

Legend: $\check{C} R$ - Czech Republic, Slovensko - Slovakia

Source: Author based on Kofola [20]

From the above picture, it is clear that Kofola has a strong market position, but Coca - Cola is still a big competitor for it. Currently (2020), Kofola 's shares increased to a record $27 \%$ in the Czech Republic and $40 \%$ in Slovakia, mainly at the expense of Coca - Cola.

Probably the problem of most of the beverage industry is the dependence on the weather in the summer months, Kofola states in its press releases that the years with long winters or floods have affected the company's profit. Also, its taste, which is very specific, may not be appreciated by everyone.

The other two areas of SWOT analysis affect the company from the external environment, which will be described in more detail in the PEST analysis.

\section{Opportunities}

- $\quad$ entry into new foreign markets

- $\quad$ advertising campaigns

- new technologies

- expansion of the product portfolio

- moving production closer to the target markets

- $\quad$ increase in market share

- $\quad$ social events

One of the opportunities is to enter a new foreign market, given that the companies already operate in several. Kofola mainly focuses on television advertising, but the strength of the Instagram social network and the addressing of so-called influencers will also appeal to a mass of potential customers. The expansion of the product portfolio can be considered another opportunity, for example, new flavours, or participation in social events such as festivals.

\section{Threats}

- financial crisis

- cheaper substitutes

- strong competition

- the ever-increasing trend of a healthy lifestyle

- fines for non-compliance with deliveries to customers (quality, time or quantity)

- $\quad$ rising energy prices

- deposit on PET bottles

- change of legislation 
Coca-Cola, a competitor, can be considered the biggest threat. Rising energy prices can also have a big impact on the company's future in the form of rising input prices, which would then make the final product more expensive. Another negative that could affect the company is the introduction of deposit PET bottles or fines for non-compliance with deliveries to customers in the required time, quality or quantity.

Marketing mix of Kofola Plc. on the Czech market

\section{Product}

Kofola drink has a very specific taste, and it is very different from other cola drinks on the Czech market. It contains less sugar and caffeine than competing products. Kofola comes with a new flavour every year, for 2020 it is Kofola Med, which falls into the Christmas limited edition.

The Kofola drink can be purchased in several types of packages and sizes, which vary according to flavours. Of course, the largest selection is at Kofola Original, which is sold in a can with a volume of 0.25 , in a glass bottle also with a volume of 0.251 and 0.331 , then a $0.51 \mathrm{can}$, which can also be purchased in the variants of Kofola Citrus and Kofola Sugar free. As for PET bottles, the range of flavours is more extensive. Kofola Original, Apricot, Melon, Raspberry, Blackberry and Gooseberry can be purchased in a PET bottle with a volume of 0.51 . It is possible to buy Kofola Original and with Guarana flavour in a 11 PET bottle. The flavours Original, Apricot and Melon can be found also in a PET bottle 1.51 and the last variant as far as PET bottles are concerned, the one with a volume of 21 can be purchased with Kofola Original, Cherry, Citrus and Sugar Free. Kofola is also sold for tap in 201 and 501 barrels.

According to the author's opinion, the packaging is very important for the product, but also its size. The Kofola drink is produced and distributed in a suitable range of packaging.

\section{Price}

As already mentioned, Kofola's price is slightly lower than that of the strongest competitors on the Czech market. The price of a 2-1 bottle is around CZK 20-30, depending on the store and whether there is currently a special offer for the given product. The same is true in restaurants where Kofola on tap is served for approximately CZK 5-6 per 1 dcl, for example, Kofola with a volume of 0.41 is cheaper than the competing Coca - Cola drink 0.331 in a glass bottle. This price is determined by each restaurant itself, the purchase price is around $1.8 \mathrm{CZK}$ per $1 \mathrm{dcl}$, so the margin is relatively high.

Keeping the price lower than the competition is the company's long-term pricing strategy.

\section{Promotion}

Kofola's marketing communication is very original and targeted directly at Czech consumers. Jannis Samaras was behind the marketing communication for a long time. He managed to put together an excellent team. In 2018, he was replaced by Daniel Buryš, who continues his work.

Communication campaigns are aimed mainly at two groups of people: young people - students between the ages of 15 and 25, who want to have fun and enjoy life. The second group are older people around the age of 50 and older, when Kofola reminds them of their youth and remembers its beginnings and its fame in the 1970's.

In its communication campaigns, Kofola places particular emphasis on love, wit and originality. This is evidenced by the advertising slogans or the very motto of the brand - " When you love her/it, no need for reason." (Note: hardly translatable wordplay). Or also the slogan for the fiftieth anniversary - "Love is no science. Kofola has known this for 50 years. "At the beginning of April 2019, Kofola released a completely new slogan for a new advertisement -" There is enough love for everyone."

The company mainly uses TV commercials, POS materials in restaurants, social networks and its website www.kofola.cz to communicate with its customers.

\section{Distribution}

Since 2015, Kofola has launched its own direct distribution of its products, especially the hotel, restaurant, and catering segment. Thanks to direct distribution, Kofola is gaining a closer and better relationship with its customers. Direct distribution has been operating in Slovakia since 2009, and thanks to the success it had there, the Czech Republic was also inspired.

As already mentioned, Kofola is distributed mainly to shops, restaurants and in the summer months to a large number of refreshment kiosks, such as near cycling routes, swimming pools, campsites and popular tourist destinations in general. It also focuses more on middle- and lower-priced restaurants as part of the competition.

In 2011, Kofola tested a complete novelty, a self-service vending machine, which should reinforce the phenomenon of lemonade on tap. The machines were applied to places where, for some reason, it is not possible to use the classic bar, which is located, for example, at some branches of the city library in Prague, where it was called Kofolík.

\section{PEST analysis of the Republic of Austria}

\section{Political and legal factors}


The Czech Republic joined the European Union in 2004, so the rules for exchanging goods are governed by the rules set out in Community legislation. Trade between EU countries is not subject to any tariff or non-tariff barriers, which used to make cross-border transport more difficult.

Goods traded are only subject to excise duty and VAT, these taxes are adjusted according to individual EU members. In Austria, VAT at the basic rate is $20 \%$ and at the reduced rate it is $10 \%$ and $13 \%$, but in the current coronavirus situation, taxes have been reduced in certain sectors till the end of 2020.

Overall, the two countries are very similar in terms of political and legal law, given that they are both members of the EU and neighbouring each other. Which in itself is a guarantee of similarity.

\section{Economic factors}

Austria is one of the richer countries in terms of GDP per capita. Austria ranks 17th in the World Bank with 52,557 mez. $\$$ and the Czech Republic in 39th place with 37,530 mez. \$. The amounts are in a hypothetical currency that would have the same value in that location as the U.S. dollar at the time.

The average wage in the Czech Republic was CZK 34,125 in 2019, calculated at $€ 1302$ at the current CNB exchange rate; this year it rose by more than CZK 1,000 to CZK 35,402 for the three quarters, which is $€ 1,350$. On the other hand, the average salary in Austria was approximately $€ 2,400$, converted to Czech crowns it was CZK 62,919, with an average of 14 salaries being paid in Austria.

Due to the current crisis, the unemployment rate has been rising steadily for the last six months, currently in November to $9.5 \%$ (7.3\% in 2019) from $8.7 \%$ in October (7.0\% in 2019). The annual inflation rate was $1.3 \%$ in November 2020 , the same as in October. Prices slowed down mainly for housing and services, alcoholic beverages, and tobacco, etc. However, inflation in food and non-alcoholic beverages remained stable.

\section{Social cultural factors}

Entrepreneurship is always influenced by the socio-cultural factors of the country. We can include all population demographics in these factors.

\section{Demographic trends}

The population of Austria by 2020 is just over 9 million and the population density is about 109 people per square kilometre. The number of citizens living in the countryside is gradually growing, currently it is $43 \%$, in 1955 it was $7 \%$ less. In 2019, the population of men was about 4.4 million and 4.5 million women.

\section{Ethnic composition and languages}

The majority of the population is Austrian 94\%, then there are Germans and Turks. In Austria, German is the official and mother tongue, but there are some differences from other German-speaking countries. There are two basic dialects in the country, Alamannisch (German) and Bairisch (Bavarian). Among other things, the original minorities also speak other languages, such as Hungarian or Slovenian.

\section{Religion}

More than half, specifically $64.1 \%$ of the population, belong to the Roman Catholic Church and $3.8 \%$ to one of the protestant churches, and about 180,000 Christians are members of the Orthodox Churches. 8,140 citizens profess Judaism.

\section{Technological factors}

Austria has made a lot of progress in research and development in the last approximately twenty years. In 1994, the research quota was $1.53 \%$, rising to $3.19 \%$ in 2020, making Austria the strongest R\&D in Europe. In the ranking of EU research spending in 2018, Austria is in second place behind Sweden (3.31\%) with $3.17 \%$. In a global comparison, Austria ranks 7 th and is therefore one of the best destinations in the field of research and development.

Austria is one of the few European countries that has exceeded the stated goal of EU research policy. However, it sets more ambitious goals: research strategy of the Federal Government considers Austria to be a leader in innovation in Europe in 2020 .

\section{Competition research on the Austrian market}

A very strong competitor for the companies is Coca-Cola HBC Austria (see Fig. 1), which is one of the largest companies in the non-alcoholic beverage industry in the country and belongs to the Cola-Cola Company and has been operating in Austria since 1929.

Another strong competitor is Almdudler, which produces a herbal drink similar to Kofola. It is the most popular drink right behind Coca-Cola. 
Pepsi is another cola drink that could come to mind for everyone in the competition of cola drinks as far as the Czech Republic is concerned, but in Austria it is not among the leading brands of carbonated soft drinks. Pepsi does not have its own branch in Austria, it is present only through Vöslauer Mineralwasser GmbH, which owns the brand's license.

\section{Results}

\subsection{Evaluation of SWOT analysis using IFE and EFE matrices}

The IFE matrix, which evaluates the company's internal factors, and the EFE matrix, which evaluates external factors, will be used to evaluate the SWOT analysis.

For each point of the IFE matrix, points in the range of 1-2 for the weak points and 3-4 for the strong ones will be assigned, and the weight in the range of $0.00-1.00$, however, the sum must be equal to 1 . It is necessary that the strengths and weaknesses are the same number, so the main ones were chosen according to the author's judgment.

Subsequently, both values will be assessed according to the IE matrix.

Table 1. IFE matrix

\begin{tabular}{|c|c|c|c|}
\hline Strengths & Points & Weight & Total \\
\hline Strong position on the Czech and Slovak market & 4 & 0,15 & 0,6 \\
\hline Financial stability & 4 & 0,1 & 0,4 \\
\hline Traditional Czech brand & 4 & 0,08 & 0,32 \\
\hline Marketing activities & 4 & 0,12 & 0,48 \\
\hline Drink composition & 3 & 0,03 & 0,09 \\
\hline Favourable price & 3 & 0,05 & 0,15 \\
\hline Customer support & 4 & 0,06 & 0,24 \\
\hline Weaknesses & - & - & - \\
\hline Number two on Czech market & 1 & 0,03 & 0,03 \\
\hline Association with communism & 1 & 0,02 & 0,02 \\
\hline Brand knowledge only in the Czech Republic and Slovakia & 2 & 0,1 & 0,2 \\
\hline Pressure on margins & 1 & 0,05 & 0,05 \\
\hline Restaurants - competitor & 1 & 0,09 & 0,09 \\
\hline Climate dependence & 1 & 0,08 & 0,08 \\
\hline Specific taste & 2 & 0,04 & 0,08 \\
\hline Total & - & 1 & 2,83 \\
\hline
\end{tabular}

Source: Author.

The EFE matrix is composed of opportunities and threats that affect the company within the external environment. As with the IFE matrix, points and weights will be allocated and the number of opportunities must be equal to the threats and vice versa. 
Table 2. EFE matrix

\begin{tabular}{|l|c|c|c|}
\hline Opportunities & Points & Weight & Total \\
\hline Entry into new foreign markets & 4 & 0,15 & 0,6 \\
\hline New technologies & 3 & 0,05 & 0,15 \\
\hline Expansion of the product portfolio & 3 & 0,05 & 0,15 \\
\hline $\begin{array}{l}\text { Moving production closer to the target } \\
\text { markets }\end{array}$ & 3 & 0,04 & 0,12 \\
\hline Increase in market share & 3 & 0,05 & 0,15 \\
\hline Advertising campaigns & 4 & 0,15 & 0,6 \\
\hline Social events & 3 & 0,05 & 0,15 \\
\hline Threats & - & - & - \\
\hline Financial crisis & 2 & 0,09 & 0,18 \\
\hline Strong competition & 2 & 0,07 & 0,14 \\
\hline Trend of a healthy lifestyle & 1 & 0,06 & 0,06 \\
\hline Fines for non-compliance with deliveries & - & 0,07 & 0,06 \\
\hline Deposit on PET bottles & 1 & 0,04 & 0,08 \\
\hline Change of legislation & $\mathbf{1}$ & 0,12 \\
\hline Cheaper substitutes & 2,63 \\
\hline Total & 2 & 0,07 \\
\hline
\end{tabular}

Source: Author.

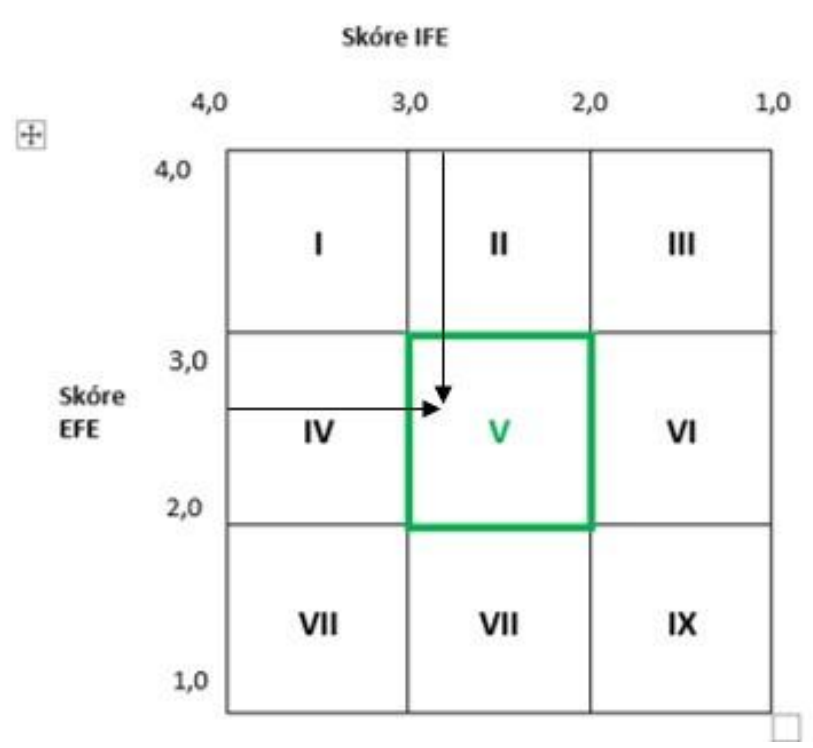

Figure 2. Matrix IE

Legend: Skóre - score

Source: Author. 
According to the results of the IFE matrix 2.83 and the EFE matrix 2.63, the company is located in quadrant number $\mathrm{V}$. in the IE matrix, which means maintenance and strengthening. Entering into new markets and development of new products is recommended. It follows that the company is strong enough to enter the Austrian market.

\subsection{Design of an adapted marketing mix for the Austrian market}

The marketing mix is the basis for the strategy of a company that wants to expand into foreign markets. Thanks to the adaptation of the marketing mix, we will get important answers to the questions that the company must address when entering new foreign markets.

\section{Product}

As far as the product is concerned, four product modifications need to be considered, namely changing the name, flavour, size of the packaging and the packaging itself.

A change of name is not necessary in this case, "Kofola" in German does not mean anything specific, so there is no need to change the name and if the drink will be sold under the same name as in Slovakia and the Czech Republic, it can only bring good feedback, because Austrians traveling to these countries may already know this drink.

Kofola is just as original, thanks to its unique taste - a mixture of herbs and licorice. As already mentioned, it contains less sugar than competing drinks, which could provoke positive reactions, but also negative ones, that the product is of lower quality due to the content of artificial sugar substitutes. Kofola is Kofola due to its unique taste, so the author believes that the taste should remain unchanged. Other flavouring variants that Kofola is enriched with are possible, such as Kofola Gooseberries, etc. In terms of positive feedback, the ever-increasing trend of a healthy lifestyle could be a plus for the drink due to the content of herbs and low sugar. To begin with, Kofola should launch both Original and Sugarfree variants on the Austrian market.

As in the Czech Republic and Austria, the standard bottle sizes are $0.51,11,1.51$ and 21 . The appearance of the packaging, not only due to the communication policy, but also a certain presentation of the product, will need to be changed. The appearance, colour structure and style should be preserved in order to unify this drink with the Czech Republic and Slovakia. The author believes that it should be clear from the packaging that it is a herbal drink, so some should be depicted on the packaging (the specific composition of these 14 herbs is known to only a handful of people, so it is not possible to state anything specific, but from the picture it should be clear that these are herbs / natural substances) which would make Kofola different from other cola drinks and could be more interesting, given that Austrians already like herbal drinks but are not associated with cola. Of course, there is also a translation of the composition, which should no longer contain anything in the Czech language, but only in the German language.

\section{Price}

The Austrian market is dominated by the large company Coca-Cola Austria, which could be said to determine the pricing policy. Other smaller companies follow it, or according to it, at least orient themselves when setting prices. The two-litre PET bottle of Coca-Cola sells for about 2.25 EUR, a bottle for 1.51 for 1.85 EUR, 11 for 1.49 EUR and 0.51 for about 1 EUR. Prices are of course indicative depending on the retail chain and any special offers.

Given that Coca-Cola Austria is the market leader, choosing a similar pricing policy seems the most appropriate. If the price were lower than the competition, the Kofola drink could give a cheap and lower quality impression. Also, the price cannot be the same as in the Czech Republic, due to different incomes. For these reasons, a price of EUR 1.25 1.49 per litre of Kofola is proposed. This price should be sufficient to make sales in Austria profitable.

\section{Communication}

Marketing communication is very key to success on the foreign market, given that Kofola is still completely unknown to Austrian customers, the right choice is the way to success. Many companies that tried to enter the Austrian market were unsuccessful due to underestimated marketing communication.

The Kofola promotion campaign should be based on its unique taste, which makes Kofola an original product. As already mentioned, Austrian customers like the herbal drink Almdudler. In the case of Kofola, this is a kind of combination of cola and herbs, so consumers should see it as a kind of compromise between competing Coca-Cola and Almdudler drinks.

Although marketing communication in the Czech Republic is based on the long tradition of this brand and love, in this case the most appropriate way of communication is not tradition and nostalgia for Austrian consumers, this image would not have to communicate anything. Promotion should focus on the natural origin of the product, unique taste, quality and, last but not least, love. It is in the Czech Republic that romantic advertising spots are very popular, which could ensure a certain popularity on the Austrian market as well.

The main motto of the advertising campaign could be the phrase "Kofola - mit Kräutern angereicherte Räder", which can be translated as "Kofola - wheels enriched with herbs" or "Kofola - der mit Liebe und Kräutern", translation "Kofola - with love and herbs " 
The communication mix can be divided into several basic forms, namely advertising, sales promotion, public relations, and direct sales. Due to the fact that Kofola is still an unknown product, investing relatively large amounts in, for example, television advertising is risky. The company is in its infancy in this market, so the author finds the following as a suitable form of communication:

\section{Advertising - press advertising}

- Press advertising should focus on magazines and periodicals rather than traditional dailies. Examples of magazines in which the advertisement could be found are, for example, Woman, Gusto, Maxima Magazin, Moments or Fizzz.

- Advertising on the Internet would complement the printed advertising, of course there would be the creation of an Austrian website, with a domain name such as kofola.at, where the customer could find any information about the product, its advantages, history and origin. Then there are the various banners on the website, which will be in the same spirit.

Sales promotion - tastings

- The product tasting could kick-start retail sales, which are controlled in Austria by three Rewe Group Retail companies, which include stores such as Billa, Penny Market or Merkur, Internationale Spar Centrale with Spar, Eurospar and Interspar, and third is Aldi. Kofola would also be sold in these stores, as Kofola is unknown, it would be risky to go on sale in restaurants and other snack establishments.

Public relations - sponsorship

- Sponsorship is very popular in Austria and all types of PR in general. The Austrian nation as well as the Czech nation loves cultural and sports events, so sponsoring a music festival such as the Donauinselfest in Vienna or the Filmfestival Rathausplatz could be the right choice. As far as sports activities are concerned, the Vienna City Marathon is held every year in Vienna, which is attended by thousands of athletes and spectators every year.

\section{Direct marketing - online marketing}

- Advertising on social networks is one of the best places to gain new customers and is also a huge player in interpersonal communication. Creating a Facebook profile, but mainly an instagram profile is the basis. Subsequent addressing of influencers who would promote the Kofola drink and organize competitions, such as foodblogger Stefanie Anich.

\section{Distribution}

There are several forms for entering the foreign market. Commercial representation, capital-intensive inputs, which can be, for example, licenses or mergers and acquisitions, which fall under capital foreign investment. As finding a suitable partner could be very difficult, none of the non-capital inputs is suitable for Kofola. These inputs could be considered if Kofola succeeds in the Austrian market, given the complexity of the inputs. The author finds the choice of entry through a sales representative or distributor the most suitable for the beginning. Kolarik \& Leeb GmbH, which has been cooperating with the Czech company Budějovický Budvar since 192, could be a potential distributor, and other possible distributors can be found on the website of the Austrian Chamber of Commerce www.wko.at. The author finds this choice to enter the foreign market the most suitable due to low risk and low entry costs. After a possible success, Kofola ČeskoSlovensko can build another subsidiary in Austria.

\section{Discussion}

The following answers to the research questions emerged from the above analyses and surveys.

1. How many competing companies operating in Austria provide a similar product?

As for the competing companies that have their own branch in Austria, the biggest competitor for Kofola Plc is the company Coca-Cola Austria, which is the market leader. Furthermore, Almdudler, which produces and sells a beverage which, with certain factors, resembles Kofola, as it contains a mixture of herbs.

If companies operating on the Austrian market through another company were also taken into account, this would be another competitor, PepciCo. However, all carbonated soft drinks that may be in competition with society may be taken into account.

It could be said that there are three major competitors in the Austrian market that provide similar.

\section{Which area of the 4P marketing mix will need to be most adapted for the selected market?}

Due to the fact that Austria is in several ways very similar to the Czech Republic, such a large adaptation of the marketing mix was not necessary. However, some changes were necessary, the biggest one could be the change in 
marketing communication, as well as the product, specifically the packaging, which required modifications at first glance, namely the language version.

\section{Conclusion}

This work is focused on the adaptation of the marketing mix to the selected country, in order to analyse both the Austrian market - competition, market entry and PEST analysis of this country, and the company's position in the Czech market and assess whether it is in a strong enough position to expand into foreign markets and subsequently design an adapted mix for the Austrian market.

The first point was the processing of the SWOT analysis of Kofola and the subsequent evaluation using the IFE, EFE and IE matrices, thanks to which it was evaluated that the company is in a sufficiently strong position to enter new markets. Furthermore, the basic marketing mix of the 4P company was described. It was subsequently adapted to the Austrian market, which resulted in an answer to one of the research questions asked, "Which area of the 4P marketing mix will need the most adaptation to the selected market?". In some respects, Austria is a very similar country to the Czech Republic, which also emerged from the PEST analysis. It was not necessary to significantly adapt all components of the mix, but the greatest need is marketing communication, which will focus more on unique taste than tradition and love like in the Czech Republic. Of course, the packaging will need to be adapted to the language version and adapted to the marketing campaign.

The next step was an analysis of competition in the Austrian market, which revealed that there are three major competitors for Kofola as, Coca-Cola Austria and Almdudler, which produces a herbal drink similar to Kofola and possibly PepsiCo, but which operates so far only represented on the Austrian market.

Given that the size of the Czech market is insufficient for such a large company, it could be said that it is necessary to expand into foreign markets. Kofola has already managed and completed it in several foreign markets, whether in the east or in the neighbouring countries of the Czech Republic, so Austria is another good opportunity for expansion.

\section{References}

1. P. Kotler, G.Armstrong. Principles of Marketing. United Kingdom: Pearson Education Limited (2017)

2. S. Godin. This is marketing: You Can't Be Seen Until You Learn to See. New York: Portfolio (2018)

3. 50 Minutes.com. The marketing mix: Master the 4 Ps of marketing. Brussels: Plurilingua Publishing (2015)

4. M. Zamazalová. Marketing obchodni firmy. Praha: Grada Publishing a. s. (2009)

5. W. Van Waterschoot, CH. van den Bulte. The 4P Classification of Maketing Mix Revisited. Journal of marketing. 56(4), 83-93 (1992)

6. R. Codita. Contingency factors of marketing-mix standardization. Berlin: Gabler Verlag (2011)

7. M. T. Khan. The Concept of 'Marketing Mix' and its Elements. International Journal of Information, Business and Management. 6(2), 95-107 (2014)

8. D. Jakubíková. Strategický marketing: strategie a trendy. Praha: Grada Publishing a. s. (2013)

9. E. Constantinides. The marketing Mix Revisited: Towards the 21st Century Marketing. Journal of Marketing Management. 22, 407-438 (2006)

10. D. Jakubíková. Marketing v cestovním ruchu: jak uspět v domácí i světové konkurenci. Praha: Grada Publishing a. s. (2012)

11. M. Baker. Marketing strategy and management. United Kingdom: Palgrave and Macmillan (2014)

12. T. Richter. International marketing mix management: Theoretical Framework, Contingency Factors and Emprical Findings from World-Markets. Berlin: Logos Verlag (2012)

13. B. Štědroň a kol. Mezinárodní marketing. Praha: C. H. Beck (2018)

14. J. Přikrylová, H. Jahodová. Moderní marketingová komunikace. Praha: Grada Publishing a. s. (2019)

15. H. Machková, E. Černohlávková, A. Sato, J. Malý, J. Sedláček. Mezinárodní obchodni operace. Praha: Grada Publishing a. s. (2014)

16. H. Machková. Mezinárodní marketing. Praha: Grada Publishing a. s. (2015)

17. M. Karlíček, M. Machek, M. Novinský, Z. Chytková, J. Dvořák, P. Bartoš, J. Koudelka, L. Tyll, R. Tahal, J. Mařík, D. Ŕiha, P. Pištělák. Základy marketingu. Praha: Grada Publishing a. s. (2018)

18. M. Palatková. Marketingový management destinací. Praha: Grada Publishing a. s. (2011) 
19. A. Gerald, J. Strandskov, E. Duerr. International Marketing and Export Management. United Kigdom: Pearson plc. (2005)

20. Kofola. Konsolidovaná výroční zpráva za rok 2018. [online]. Available at: https://investor.kofola.cz/wpcontent/uploads/2019/05/08-annual-report-2018-kofola-ceskoslovensko-cz-

_70eab829fa24c9478021e58e117881f7.pdf 